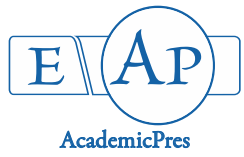

\title{
The Effects of Wheat Flour and Barley Flour on the Quality and Properties of Biscuits Colored with Synthetic and Natural Colorants
}

\author{
Abeer A. AMER ${ }^{1}$, Hossam S. EL-BELTAGI ${ }^{2,3 *}$, Rehab F. M. ALI ${ }^{2,4}$, \\ Somia M. MOUSA ${ }^{1}$, Emam ABDEL-RAHIM ${ }^{2}$ \\ ${ }^{1}$ Food Technology Research Institute, Agricultural Research Center, Giza, Egypt \\ ${ }^{2}$ Cairo University, Faculty of Agriculture, Biochemistry Department, P. Box 12613, Gamma St, Giza, Cairo-Egyp; \\ belbeltagi@agr.cu.edu.eg (*orresponding author) \\ ${ }^{3}$ King Faisal University, College of Agriculture and Food Sciences, Agriculture Biotechnology Department, \\ P.O. Box 420, Alhassa 31982, Saudi Arabia \\ ${ }^{4}$ Al-Qassim University, College of Agriculture and Veterinary Medicine, Department of Food Science and Human Nutrition, Qassim, \\ Kingdom of Saudi Arabia
}

\begin{abstract}
Biscuit is one of the most popular processed ready to eat snacks that have possesses several attractive features including wide consumer base, relatively less expensive, more convenient with long shelf-life and have ability to serve as vehicles for important nutrients. It's usually available in different sizes, tastes and shapes. It can also be enriched or fortified with other ingredients in order to meet specific nutritional or therapeutic needs of consumers. In recent years, numerous studies have shown the potential of utilizing natural plant such as green leafy vegetable in cookies and biscuit production; the potential of amaranthus leaves used as a source of iron and $\beta$-carotene inpakora, vada, namakpal, kurmure, biscuit and cake. The present research was carried out to throw the light on the effect of wheat flour and barley flour with natural and synthetic colors to improve chemical composition, the nutritional value and quality characteristics of producing biscuits. The results indicate that that treatment $100 \%$ barley flour $72 \%$ with turmeric and cocoa as a natural colors recorded a significant increase in the content of protein, ash, minerals such as iron, zinc, potassium, magnesium and some physical analysis like weight, volume, density as well as sensory evaluation. As compared with wheat flour $72 \%$ and synthetic color tartrazine ADI $7.5 \mathrm{mg} / \mathrm{kg} . b w$ and chocolate brown ADI $0.15 \mathrm{mg} / \mathrm{kg} . b w$. In conclusion, results showed that barley flour improved nutritional quality, physical characteristics and sensory characteristics of produce biscuit with mixture natural and natural color.
\end{abstract}

Keywords: biscuit; chemical composition; natural colors; physical and sensory characteristics; synthetic colors

\section{Introduction}

Wheat (Triticum aestivum L.) is a cereal cultivated worldwide and has great importance in the human diet, contributing as a direct source of energy, protein, vitamins, minerals and fiber (Karl and Saltzman, 2012; Mckeown, 2013; El-Beltagi and Abdel-Rahim, 2017). Almost all wheat grains are intended for the production of flour, typically used in the preparation of breads, pastas and cakes. The bran originating from its processing has high fiber content and it is widely consumed, either directly or as an ingredient in prepared foods. Wheat flour $72 \%$ extraction contained $11.66 \%$ moisture, $11.83 \%$ protein, $1.01 \%$ fat, $0.53 \%$ ash, $0.38 \%$ fiber and $86.25 \%$ total carbohydrate (Dahab 2006).

Barley (Hordeum vulgare), is the world's most nutritional crop. This is because it contains many elements that rich sources of health and energy. The composition of barley, including the percentage of minerals, barley flour contained $11.65 \%, 2.31 \%, 6.25 \%$ and $2.22 \%$ crude protein, fat, fiber and ash respectively. Another variety of barley flour contained $15 \%$ crude protein, $2.19 \%$ crude fat, $3.2 \%$ ash, $15.81 \%$ dietary fiber, $63.8 \%$ total carbohydrates and $5.62 \%$ total carbohydrates and $5.62 \%$-glucan on dry weight basis (Hassan et al., 2012). Barley meal characterized by $\beta$-glucan, which ranged from 3 up to $7 \%$, whereas $\beta$-glucan ranged from 38.9 up to $50.2 \mathrm{~g} / \mathrm{k} \mathrm{g}$ for covered barley and it was higher in hull less barley $(43.8-62.3 \mathrm{~g} / \mathrm{kg})$. Ash percentage in barley meal was between 1.92 up to 3\%, these results were concluded by Abdel-Rahim et al. (1987).

Biscuits are convenient food products and the most popular bakery items consumed by nearly all levels of society in Egypt. Some of the reasons for such wide popularity are low cost among other processed foods, good nutritional quality and availability in different varieties and varied taste (Sudha et al., 2007). The major ingredients are flour, fat, sugar and water while other ingredients such as milk, salt and aerating agent can be included. 
Dyes of synthetic color are complex organic chemicals that were originally derived from coal tar, but now from petroleum. Companies prefer using them because they are cheaper, more stable, and brighter than most natural colorings. However, changing consumer preferences play an important role in how rituals and companies market their products and lead to replace synthetic coloring by heather natural coloring, such as beta-carotene (a precursor to vitamin A), paprika, beet juice, and turmeric. That trend is stronger in Europe than the United States, but some U.S. companies recognize that an "All Natural" label can attract customers and may be moving in that direction. Two recent studies sponsored by the British government on crosssections of British children found that mixtures of four dyes (and a food preservative, sodium benzoate) impaired the behavior of even non-hyperactive children (Barrett $e t$ al., 2007). The acceptable daily of Tartrazine intake (ADI) of human is $0-7.5 \mathrm{mg} / \mathrm{kg} /$ day (Walton et al., 1999). The metabolism of tartrazine was well documented in animals and humans in a range of doses, the absorption of oral administration of intact less than 5\% (Feng et al., 2012) while, the ADI for chocolate brown is $0.15 \mathrm{mg} / \mathrm{kg} /$ day (FAO/WHO 1985).

Turmeric (Curcuma longa) as natural color is extensively used as spice, food preservative and coloring material. It has been used in traditional medicine as a household remedy for various diseases, including biliary disorders, anorexia, cough, diabetic wounds, hepatic disorders, rheumatism and sinusitis (Ammon and Wahl, 1991). For the last few decades, extensive work has been done to establish the biological activities and pharmacological actions of turmeric and its extracts. Curcumin (diferuloylmethane, the main yellow bioactive component of turmeric) has been shown to have a wide spectrum of biological actions. These include its antiinflammatory, antioxidant, anticarcinogenic, antimutagenic, anticoagulant, antifertility, antidiabetic, antibacterial, antifungal, antiprotozoal, antiviral, antifibrotic, antivenom, antiulcer, hypotensive and hypocholesteremic activities. Its anticancer effect is mainly mediated through induction of apoptosis. Its antiinflammatory, anticancer and antioxidant roles may be clinically exploited to control rheumatism, carcinogenesis and oxidative stress-related pathogenesis (AOAC, 2000)

Cocoa (Theobroma cacao L) has been reported to contain significant amount of dietary flavonoids and exhibit greater antioxidant capacity than many other flavanol rich foods (Lee et al., 2003). The health benefits associated with cocoa consumption have been related to their capacity to improve the lipid profile and insulin sensitivity, diminish blood pressure, reduce platelet activity and function, ameliorate endothelial dysfunction and act as antioxidants (Monagas et al., 2009). These health benefits of cocoa have been attributed to their high polyphenol compounds, mainly flavanols (Stahl et al., 2009). Cocoa powder is used in confectionery products and also in non-confectionery products such as flavored milks, cereals, ice cream, cookies, biscuits, cakes, and other dessert. The aim of this study is to investigate the effect of synthetic color powder and natural color powder level and effect of mixed color on the quality characteristics and properties by wheat biscuit and barley biscuit.

\section{Materials and Methods}

\section{Materials}

Wheat flour (72\% extraction) was obtained from Wheat Research Section Field Crops Research Institute, Agricultural Research Center, Giza, Egypt.Barley flour (naked barley) (Hordium vulgar L.) Giza 130, obtained from Barley Research Section, Field Crops Research Institute, Agricultural Research Center, Giza, Egypt, which was milling in the Corps Technology Institute. Sugar, shortening, vanilla, egg, baking powder and salt (sodium chloride): were obtained from the local market of Giza, Egypt. Natural color: as turmeric and cocao powder were obtained from the local market of Giza, Egypt.Synthetic color: as tartrazine yellow and chocolate brown color were obtained from Imperial Chemical Industries. Mixed color as Tartrazine/Turmeric and Cocao/Chocolate brown mixture were prepared by adding each one to the other in ratio of $1: 1\left(w^{\prime} / \mathrm{w}\right)$. All chemicals used in this study were analytical grade.

\section{Determination of proximate analysis}

Moisture, protein, fiber, lipid and ash were determined as reported in AOAC (2000). Total carbohydrate was calculated by difference.

\section{Determination of dietary fiber}

Total dietary fiber (TDF) was determined according to the method described by Prosky et al. (1984).

\section{Calculation:}

Mg residue - [(\% protein in residue $+\%$ ash in residue $) \times$ mg residue] $\times 100 /$ sample weight

\section{Determination of elements content}

Total content of $\mathrm{K}, \mathrm{Na}, \mathrm{Fe}, \mathrm{Zn}, \mathrm{Ca}, \mathrm{Mg}$ and $\mathrm{P}$ was determinate according to the method described by AOAC (2000).

\section{Determination of chromium}

Chromium was determined according to the method described by Jackson et al. (2000).

\section{Biscuit formula and ingredients}

Control biscuit dough was prepared according to the formula presented in Table 1 (Wade, 1988).

\section{Physical characteristics of biscuits}

Physical characteristics were determined according to previous method described (Sai- Manohar and Rao, 1997). The diameter and thickness of five biscuits were measured by placing those edges and stacking one above the other respectively. To obtain the average, measurements were made by rearranging and restocking. The spread ratio was obtained by the ratio between diameter and thickness. The average weight of five biscuits was recorded. Volume $\left(\mathrm{cm}^{3}\right)$ was determined. The bulk density was calculated and expressed as $\mathrm{g} / \mathrm{m}^{3}$.

Spread ratio $=$ Width $/$ Height

Spread factor ratio $=$ Spread factor of sample $/$ Spread factor of control 
32

Table 1. Formula of biscuit (wheat and barley) flour preparation

\begin{tabular}{ccccccccc}
\hline Biscuit treatments & Flour & Sugar & Shortening & Dye & Vanilla & Egg & Baking powder & Salt \\
\hline G1 & $100 \mathrm{~g}$ & $30 \mathrm{~g}$ & $30 \mathrm{~g}$ & Less dye & $1-2 \mathrm{~g}$ & $15 \mathrm{mg}$ & $2-3 \mathrm{~g}$ & $1 \mathrm{~g}$ \\
G2 & $100 \mathrm{~g}$ & $30 \mathrm{~g}$ & $30 \mathrm{~g}$ & $7.5 \mathrm{mg} / \mathrm{kg}(\mathrm{bw}) /$ day & $1-2 \mathrm{~g}$ & $15 \mathrm{mg}$ & $2-3 \mathrm{~g}$ & $1 \mathrm{~g}$ \\
G3 & $100 \mathrm{~g}$ & $30 \mathrm{~g}$ & $30 \mathrm{~g}$ & $0.15 \mathrm{mg} / \mathrm{kg}(\mathrm{bw}) /$ day & $1-2 \mathrm{~g}$ & $15 \mathrm{mg}$ & $2-3 \mathrm{~g}$ & $1 \mathrm{~g}$ \\
G4 & $100 \mathrm{~g}$ & $30 \mathrm{~g}$ & $30 \mathrm{~g}$ & $7.5 \mathrm{mg} / \mathrm{kg}(\mathrm{bw}) /$ day & $1-2 \mathrm{~g}$ & $15 \mathrm{mg}$ & $2-3 \mathrm{~g}$ & $1 \mathrm{~g}$ \\
G5 & $100 \mathrm{~g}$ & $30 \mathrm{~g}$ & $30 \mathrm{~g}$ & $0.15 \mathrm{~g} / \mathrm{kg}(\mathrm{bw}) /$ day & $1-2 \mathrm{~g}$ & $15 \mathrm{mg}$ & $2-3 \mathrm{~g}$ & $1 \mathrm{~g}$ \\
G6 & $100 \mathrm{~g}$ & $30 \mathrm{~g}$ & $30 \mathrm{~g}$ & $15 \mathrm{mg} / \mathrm{kg}(\mathrm{bw}) /$ day & $1-2 \mathrm{~g}$ & $15 \mathrm{mg}$ & $2-3 \mathrm{~g}$ & $1 \mathrm{~g}$ \\
G7 & $100 \mathrm{~g}$ & $30 \mathrm{~g}$ & $30 \mathrm{~g}$ & $0.3 \mathrm{~g} / \mathrm{kg}(\mathrm{bw}) /$ day & $1-2 \mathrm{~g}$ & $15 \mathrm{mg}$ & $2-3 \mathrm{~g}$ & $1 \mathrm{~g}$ \\
\hline
\end{tabular}

G1: control biscuits less color, G2: Turmeric biscuits, G3: cacao biscuits, G4: Tartrazine color biscuits, G5: chocolate brown color biscuits, G6: Mixure tartrazine/Turmeric biscuits and G7: Mixture Cacao/chocolate brown biscuits.

\section{Sensory evaluation of biscuits}

The sensory characteristics of biscuits were evaluated according to previous study (Farhath, 2001) and were carried out by panel of ten adults experienced Judes from the staff of the food Technology Research Institute, Agriculture Research Center,Giza, Egypt and by children. Assigning scores for various quality attributes such as: color (20), taste (20), texture (20), crust appearance (20), oder (20), overall acceptability (100).

The average total score was converted to a descriptive category as follows: very good $90-100$ [VG], good $80<90$ $[\mathrm{G}]$, satisfactory $70<80[\mathrm{~S}]$, questionable less than $70[\mathrm{Q}]$.

\section{Statistical analysis}

Values are presented as means \pm SEM. Statistical analysis was carried out using the "costat" statistic computer program. Statistical analysis was based on One-way analysis of variance ANOVA followed by student-Newman Keuls test, and least significant difference (LSD) at $\mathrm{P}<0.05$.

\section{Results and Discussion}

Chemical composition of cocoa and turmeric powder

Data on chemical composition of cocoa and turmeric powder are presented in Table 2 showed that cocoa powder was higher in protein content $21.6 \%$ and lipid $55.2 \%$ and lower in crude fiber $5.22 \%$, dietary fiber $4.5 \%$ than that of turmeric powder, that have a protein content of $8.31 \%$, lipid $9.10 \%$, crude fiber $7.12 \%$, and dietary fiber $28.12 \%$. Farhath et al. (2001) reported that turmeric contains $72 \%$ water, $1.4 \%$ ash, 8.53 crud fibers, $31.21 \%$ starch.

\section{The chemical composition of barley flour and wheat flour}

The chemical composition of wheat flour extraction and barley flour (Table 3) reflects that moisture content was higher in wheat flour $72 \%$ than in barley flour, whereas protein in wheat flour $72 \%$ was about equal of barley flour. Fat and ash contents were higher in barley flour comparing with wheat flour $72 \%$, fiber content in barley flour was higher than that of wheat flour $72 \%$. Chemical analysis of the raw materials indicated that carbohydrate content was higher in wheat flour $72 \%$ than that of barley flour. $\beta$-glucan content in barley flour represented the superiority (6.30 $\mathrm{mg} / \mathrm{g}$ ) as compared wheat flour. These results are in agreement with Dahab (2006) who got similar results in previous study. The primary constituents of barley kernel as reported are starch $(52-71 \%)$, protein (8-13\%), lipids (2$3 \%)$, non-starch polysaccharides, and protein of $\beta$ - glucan (3-11\%) (MacGregor and Fincher, 1993). Barley is now gaining a renewed interest as a functional food ingredient because it is considered as a rich source of $\beta$ - Glucan (Brennan and Cleary, 2005).

Table 2. Chemical composition of cocoa and turmeric powder (\%)

\begin{tabular}{ccc}
\hline Chemical analysis & Cocoa powder & Turmeric powder \\
\hline Moisture & $4.2 \pm 0.06^{\mathrm{b}}$ & $8.46 \pm 0.27^{\mathrm{a}}$ \\
Ash & $3.6 \pm 0.04^{\mathrm{b}}$ & $6.51 \pm 0.11^{\mathrm{a}}$ \\
Protein & $21.5 \pm 0.53^{\mathrm{a}}$ & $8.31 \pm 0.13^{\mathrm{b}}$ \\
Crude fiber & $5.4 \pm 0.09^{\mathrm{b}}$ & $7.12 \pm 0.10^{\mathrm{a}}$ \\
lipid & $45.8 \pm 0.17^{\mathrm{a}}$ & $9.10 \pm 0.12^{\mathrm{b}}$ \\
Carbohydrate & $15.1 \pm 0.31^{\mathrm{b}}$ & $57.68 \pm 1.46^{\mathrm{a}}$ \\
Dietary fiber & $4.4 \pm 0.05^{\mathrm{a}}$ & $2.82 \pm 0.22^{\mathrm{b}}$ \\
\hline
\end{tabular}

Table 3. Chemical composition of raw flour

\begin{tabular}{|c|c|c|c|c|c|c|c|c|c|}
\hline \multirow{2}{*}{$\begin{array}{c}\text { Chemical } \\
\text { Composition }\end{array}$} & \multirow[b]{2}{*}{ Moisture \% } & \multirow[b]{2}{*}{ Protein \% } & \multirow[b]{2}{*}{ Fat $\%$} & \multirow[b]{2}{*}{ Ash \% } & \multirow{2}{*}{$\begin{array}{c}\text { Crude fiber } \\
\%\end{array}$} & \multirow{2}{*}{$\begin{array}{c}\text { Total } \\
\text { Carbohydrate } \\
\%\end{array}$} & \multicolumn{3}{|c|}{$\beta$-Glucan } \\
\hline & & & & & & & Soluble & Insoluble & Total \\
\hline $\begin{array}{c}\text { Barley flour } \\
72 \%\end{array}$ & $7.53 \pm 0.17^{b}$ & $12.01 \pm 0.23^{\mathrm{a}}$ & $2.75 \pm 0.01^{\mathrm{a}}$ & $2.40 \pm 0.02^{a}$ & $2.68 \pm 0.02^{\mathrm{a}}$ & $80.16 \pm 2.11^{\mathrm{b}}$ & $2.00 \pm 0.01$ & $4.30 \pm 0.02$ & $6.30 \pm 0.02$ \\
\hline $\begin{array}{c}\text { Wheat flour } \\
72 \%\end{array}$ & $11.66 \pm 0.24^{a}$ & $11.83 \pm 0.19^{a}$ & $1.51 \pm 0.01^{\mathrm{b}}$ & $0.53 \pm 0.01^{\mathrm{b}}$ & $0.38 \pm 0.02^{\mathrm{b}}$ & $85.75 \pm 1.99^{\mathrm{a}}$ & -.. & -- & -- \\
\hline
\end{tabular}




\section{Chemical composition of the produced biscuit}

Table 4 shows the chemical composition of biscuits contained different levels of the natural color (turmeric powder and cocoa powder), synthetic color (tartrazien and chocolate brown). From the data, it could be observed that, biscuits formulated with natural color $7.5 \mathrm{mg} / \mathrm{kg}$ level of turmeric powder had a slightly high contents of moisture, ash, protein, fiber, fat, dietary fiber and slightly low content of carbohydrates than that of control biscuits. On the other hand, biscuits formulated with $0.15 \mathrm{mg} / \mathrm{kg}$ cocoa powder contained higher content of moisture, ash, protein, crude fiber, fat, and dietary fiber than that of biscuits control. This result is in agreement with the data of Ajibola et al. (2015), who found that, significant increase in moisture, ash, protein and fiber content of wheat biscuits with addition of Moringa oleifera leaves and cocoa powder. The moisture content of cocoa biscuits ranged from 3.05 to $3.76 \%$. The protein and fat content varied from 10.99 to $14.73 \%$ and 13.19 to $15.00 \%$, respectively. The ash, fiber and carbohydrate contents ranged from 2.23 to $2.63 \%, 2.45$ to $4.35 \%$ and 64.77 to $69.86 \%$, respectively. There was significant increase in protein and fiber content of biscuits with addition of cocoa powder with the high protein and fiber contents observed in samples compared of control. Biscuits formulated with synthetic color $7.5 \mathrm{mg} / \mathrm{kg}$ tartrazien had a slightly low content of moisture, ash, protein, crud fiber, fat, dietary fiber and carbohydrates as compared with control biscuits. The same trend for biscuits formulated with $0.15 \mathrm{mg} / \mathrm{kg}$ of chocolate brown had a slightly low contents of protein, fiber, fat, dietary fiber and slightly low content of carbohydrates than that of control biscuits. On the other hand, biscuits made mixture synthetic color and natural color had the same values of protein, fiber, fat and dietary fiber as compared with biscuits control.

\section{Minerals content of the produced biscuits}

The element contents of the produced biscuits formulated with the powdered of color, turmeric and cocoa are presented in Table 5. From the obtained result, it could be seen that biscuits formulated with cocoa powder had higher contents of potassium with two supplements (64.21 and 66.19), magnesium, (12.35 and 15.13), calcium (58.31 and 61.76) and phosphorus (17.50 and 19.91) $\mathrm{mg} / 100 \mathrm{~g}$, respectively and iron (0.20 and 0.63$)$. These results are in good agreement with those reported by Ajibola et al. (2015), who reported that the iron content of wheat biscuit flour was $1.57 \mathrm{mg} \%$, which increased significantly when incorporated with cocoa powder.

The calcium content of biscuits increased from 29.17 $\mathrm{mg} \%$ to $52.47 \mathrm{mg} \%$ when cocoa powder was added to the biscuits. The significant increase in the calcium content could be due to the presence of higher calcium content in cocoa powder. The results indicate that cocoa powder supplemented biscuits possess higher nutritive profile than the control biscuit with significant increase in protein, fiber, iron and calcium. Similar improvements in the nutritional characteristics, such as dietary fiber, protein, iron and calcium have been reported for green leafy vegetables-supplemented cookies and biscuits than that of biscuits made of chocolate brown (Drisya et al., 2015). On the other hand biscuits formulated with the powder of turmeric contained potassium (74.37), magnesium $(5.41 \mathrm{mg})$, iron $(1.66 \mathrm{mg})$, calcium $(5.5 \mathrm{mg})$ and phosphorus $(9.54 \mathrm{mg})$. The main mineral predominance in the powder of turmeric is chromium $(700.65 \mathrm{mg} / 100 \mathrm{~g}$ ) Table 4 . Biscuits formulated with the powdered or oil of turmeric contained good values of chromium, respectively.

Table 4. Chemical composition (\%) of colored wheat flour biscuit

\begin{tabular}{cccccccc}
\hline Biscuit treatments & Moisture & Ash & Protein & Crude fiber & Fat & Carbohydrate & Dietary fiber \\
\hline G1 & $4.78 \pm 0.31^{\mathrm{a}}$ & $1.31 \pm 0.10^{\mathrm{a}}$ & $6.77 \pm 0.41^{\mathrm{a}}$ & $0.22 \pm 0.01^{\mathrm{a}}$ & $13.13 \pm 0.90^{\mathrm{a}}$ & $70.63 \pm 1.02^{\mathrm{b}}$ & $3.16 \pm 0.22^{\mathrm{b}}$ \\
G2 & $5.12 \pm 0.29^{\mathrm{a}}$ & $1.49 \pm 0.09^{\mathrm{a}}$ & $6.80 \pm 0.38^{\mathrm{a}}$ & $0.39 \pm 0.02^{\mathrm{a}}$ & $13.38 \pm 1.08^{\mathrm{a}}$ & $68.49 \pm 1.11^{\mathrm{c}}$ & $3.88 \pm 0.19^{\mathrm{a}}$ \\
G3 & $4.79 \pm 0.27^{\mathrm{a}}$ & $1.21 \pm 0.07^{\mathrm{a}}$ & $5.75 \pm 0.32^{\mathrm{ab}}$ & $0.21 \pm 0.01^{\mathrm{a}}$ & $13.01 \pm 0.81^{\mathrm{a}}$ & $72.83 \pm 1.12^{\mathrm{b}}$ & $2.20 \pm 0.14^{\mathrm{c}}$ \\
G4 & $5.04 \pm 0.28^{\mathrm{a}}$ & $1.51 \pm 0.10^{\mathrm{a}}$ & $6.88 \pm 0.41^{\mathrm{a}}$ & $0.32 \pm 0.02^{\mathrm{a}}$ & $13.90 \pm 0.82^{\mathrm{a}}$ & $68.57 \pm 1.12^{\mathrm{c}}$ & $3.78 \pm 0.22^{\mathrm{a}}$ \\
G5 & $4.60 \pm 0.36^{\mathrm{a}}$ & $1.22 \pm 0.09^{\mathrm{a}}$ & $6.17 \pm 0.40^{\mathrm{a}}$ & $0.20 \pm 0.01^{\mathrm{a}}$ & $9.13 \pm 0.60^{\mathrm{b}}$ & $76.47 \pm 0.94^{\mathrm{a}}$ & $2.21 \pm 0.18^{\mathrm{c}}$ \\
G6 & $4.78 \pm 0.35^{\mathrm{a}}$ & $1.30 \pm 0.07^{\mathrm{a}}$ & $6.78 \pm 0.39^{\mathrm{a}}$ & $0.23 \pm 0.01^{\mathrm{a}}$ & $13.16 \pm 0.71^{\mathrm{a}}$ & $70.59 \pm 0.82^{\mathrm{b}}$ & $3.16 \pm 0.19^{\mathrm{b}}$ \\
G7 & $4.77 \pm 0.34^{\mathrm{a}}$ & $1.31 \pm 0.07^{\mathrm{a}}$ & $6.79 \pm 0.41^{\mathrm{a}}$ & $0.22 \pm 0.01^{\mathrm{a}}$ & $13.12 \pm 0.88^{\mathrm{a}}$ & $70.62 \pm 0.71^{\mathrm{b}}$ & $3.17 \pm 0.17^{\mathrm{b}}$ \\
\hline
\end{tabular}

G1: control Biscuits less color, G2: Biscuits turmeric powdered, G3: Biscuits contained cocoa powdered, G4: Biscuits contained tartrazine, G5: Biscuits contained chocolate brown powdered, G6: Biscuits contained mixture Turmeric / Tartrazine powdered, G7: Biscuits contained cocoa/ chocolate brown powdered. Values are mean \pm SD of three-replicates

Table 5. Minerals content of the colored wheat flour biscuit (mg/100g dry weight)

\begin{tabular}{ccccccccc}
\hline Biscuit treatments & $\mathrm{Na}$ & $\mathrm{K}$ & $\mathrm{Mg}$ & $\mathrm{Fe}$ & $\mathrm{Zn}$ & $\mathrm{Ca}$ & $\mathrm{P}$ & $\mathrm{Cr}$ \\
\hline G1 & $0.31 \pm 0.001^{\mathrm{c}}$ & $0.853 \pm 0.005^{\mathrm{f}}$ & $0.29 \pm 0.001^{\mathrm{e}}$ & $0.38 \pm 0.002^{\mathrm{b}}$ & $0.01 \pm 0.001^{\mathrm{c}}$ & $38.85 \pm 0.03^{\mathrm{c}}$ & $0.98 \pm 0.005^{\mathrm{d}}$ & $\cdots$ \\
G2 & $1.22 \pm 0.012^{\mathrm{cd}}$ & $74.370 \pm 0.53^{\mathrm{a}}$ & $5.41 \pm 0.032^{\mathrm{d}}$ & $1.67 \pm 0.005^{\mathrm{a}}$ & $0.19 \pm 0.004^{\mathrm{a}}$ & $35.50 \pm 0.03^{\mathrm{e}}$ & $9.54 \pm 0.04^{\mathrm{c}}$ & $20.4 \pm 0.013^{\mathrm{a}}$ \\
G3 & $2.91 \pm 0.013^{\mathrm{b}}$ & $64.21 \pm 0.42^{\mathrm{c}}$ & $12.35 \pm 0.011^{\mathrm{b}}$ & $0.20 \pm 0.001^{\mathrm{c}}$ & $0.09 \pm 0.001^{\mathrm{b}}$ & $58.31 \pm 0.04^{\mathrm{a}}$ & $17.50 \pm 0.01^{\mathrm{a}}$ & $\cdots$ \\
G4 & $1.34 \pm 0.004^{\mathrm{d}}$ & $20.15 \pm 0.17^{\mathrm{e}}$ & $5.51 \pm 0.036^{\mathrm{d}}$ & $0.13 \pm 0.001^{\mathrm{d}}$ & $0.20 \pm 0.001^{\mathrm{a}}$ & $38.62 \pm 0.03^{\mathrm{c}}$ & $0.61 \pm 0.002^{\mathrm{e}}$ & $\cdots$ \\
G5 & $0.40 \pm 0.001^{\mathrm{e}}$ & $0.96 \pm 0.004^{\mathrm{f}}$ & $0.32 \pm 0.002^{\mathrm{e}}$ & $0.03 \pm 0.001^{\mathrm{e}}$ & $0.02 \pm 0.001^{\mathrm{c}}$ & $37.34 \pm 0.02^{\mathrm{d}}$ & $0.89 \pm 0.003^{\mathrm{d}}$ & $\cdots$ \\
G6 & $3.60 \pm 0.020^{\mathrm{a}}$ & $71.3 \pm 0.41^{\mathrm{b}}$ & $6.96 \pm 0.039^{\mathrm{c}}$ & $0.03 \pm 0.001^{\mathrm{c}}$ & $0.02 \pm 0.001^{\mathrm{c}}$ & $37.50 \pm 0.02^{\mathrm{d}}$ & $0.60 \pm 0.002^{\mathrm{e}}$ & $20.0 \pm 0.014^{\mathrm{a}}$ \\
G7 & $2.61 \pm 0.01^{\mathrm{c}}$ & $60.21 \pm 0.40^{\mathrm{d}}$ & $13.35 \pm 0.010^{\mathrm{a}}$ & $0.10 \pm 0.003^{\mathrm{d}}$ & $0.02 \pm 0.001^{\mathrm{c}}$ & $56.31 \pm 0.03^{\mathrm{b}}$ & $16.5 \pm 0.006^{\mathrm{b}}$ & $\cdots$ \\
\hline
\end{tabular}

G1: control Biscuits less color, G2: Biscuits turmeric powdered, G3: Biscuits contained cocoa powdered, G4: Biscuits contained tartrazine, G5: Biscuits contained

chocolate brown powdered, G6: Biscuits contained mixture Turmeric / Tartrazine powdered, G7: Biscuits contained cocoa/ chocolate brown powdered.

Values are mean \pm SD of three replicates 
34

\section{Physical properties of the colored biscuits}

Physical characteristics of biscuits formulated with different levels of cocoa powder are presented in Table 6. It could be observed, that the addition of cocoa powder had a considerable slight effect on biscuit quality. The diameter and thickness slightly decreased up to the level. At the two levels $(15$ and $30 \mathrm{mg} / \mathrm{kg}$ ) the diameter and thickness slightly decreased compared with the control. While density at all the levels of cocoa powder almost had the same values. This is possibly due to the addition of increasing levels of cocoa powder which did not affect on crispness of the produced biscuits.

From Table 6 it could be noticed that, the physical properties of biscuits formulated with different level of turmeric powder $(7.5 \mathrm{mg} / \mathrm{kg})$ had the same trend as biscuits formulated with cocoa powder. Diameter and thickness decreased by increasing the levels of turmeric powder and cocoa powder. While spread ratio increased by increasing the levels of turmeric powder and cocoa powder. While density almost the same, the density slightly increased. From the results it could be seen that increasing the density with increasing the levels of powder, indicate to the crispness had too low.

The replacement of wheat flour with increasing level of color powder decreased the spread ratio from 1.95 to 1.57and 1.33 in turmeric 1.10 and 1.11 in tartrazine, 1.53 and 1.84 in cocoa and 1.76 and 1.72 in chocolate brown due to the decrease and increase in diameter and thickness, respectively. Similar results had been reported for cookies prepared from composite flour (Drisya et al., 2015). The observed decrease in spread ratio has been attributed to dilution of gluten and less water available for gluten hydration (Sharma et al., 2013). The use of composite flour increases dough viscosity and forms aggregates of competing with limited free water available in cookie dough (McWatters, 1978).

\section{Sensory characteristics of the produced biscuits}

There are significant differences between the different kind of biscuits and the different powder levels of turmeric and tartrazine (Table 7). The highest score of color was recorded for biscuits formulated with $7.5 \mathrm{mg} / \mathrm{kg}$ levels of turmeric powder and tartrazine, while the lowest score of color was observed with biscuits formulated with mixture between turmeric and tartrazine. The addition of different levels of turmeric powder improved the taste of the prepared biscuit; there was a significant difference with mixture between turmeric and tartrazine. At the same line, there were also improved in odor of biscuits made using different levels of the powder. Crust appearance had no significant between biscuits formulated with levels of turmeric powder. While, texture of biscuits made using mixture had the highest score. The addition of turmeric powder improved the overall acceptability up to the mixture. The mixture had no accepted as the other level of turmeric and tartrazine powder.

Data pertaining to sensory evaluation of biscuits formulated with different levels of turmeric. The present results revealed that the addition of turmeric at all the studied levels improved color, crust appearance and texture. While taste and odor had improved up to mixture level of turmeric and tartrazine, biscuits made using mixture level had a significant difference with the other levels (Boskou et al., 2010). From the data in Table 7, it could be concluded that biscuits made using of the powder of turmeric were very good accepted by panelists than biscuit tartrazine powder.

The sensory characteristics of biscuits supplemented with cocoa are presented in Table 8 . The sensory scores for color, odor and taste of all the supplemented biscuits were lower when compared to those of control. The color and taste of sample biscuits containing cocoa were more acceptable than those of control. This could be attributed to the addition of cocoa, which helped to mask the greenish color and improved the taste of the biscuit. Past studies had reported the changes in color. The overall acceptability scores were $97.5 \%$ and $97.4 \%$ of cocoa sample, respectively. The results show that acceptable biscuits could be prepared using the addition of cocoa powder more acceptable color and taste. The addition of cocoa powder to biscuits supplemented with cassava flour enhanced the flavor and color of the biscuits (Gyedu-Akoto and Laryea, 2013).

Table 6. Physical properties of colored wheat flour biscuits made using the natural color and synthetic color $(\mathrm{mg} / 100 \mathrm{~g}$ dry weight)

\begin{tabular}{|c|c|c|c|c|c|}
\hline Biscuit & Width $^{\mathrm{s}}(\mathrm{cm})$ & Thickness $^{\mathrm{b}}(\mathrm{cm})$ & Spread ratio $^{c}$ & Spread factor $^{\mathrm{d}}$ & Density $\mathrm{g} / \mathrm{cm}^{3}$ \\
\hline G1 & $4.6 \pm 0.12^{a}$ & $2.35 \pm 0.08^{e}$ & $1.95 \pm 0.012^{\mathrm{a}}$ & $100 \pm 2.71^{a}$ & $0.64 \pm 0.002^{\mathrm{a}}$ \\
\hline G2 & $4.1 \pm 0.11^{b}$ & $2.60 \pm 0.07^{d}$ & $1.57 \pm 0.011^{c}$ & $92.01 \pm 1.43^{\mathrm{b}}$ & $0.67 \pm 0.001^{\mathrm{a}}$ \\
\hline G3 & $4.6 \pm 0.14^{\mathrm{a}}$ & $3.00 \pm 0.10^{c}$ & $1.53 \pm 0.010^{c}$ & $102 \pm 1.99^{\mathrm{a}}$ & $0.64 \pm 0.002^{\mathrm{a}}$ \\
\hline G4 & $4.2 \pm 0.16^{b}$ & $3.81 \pm 0.09^{\mathrm{a}}$ & $1.10 \pm 0.010^{\mathrm{d}}$ & $61.03 \pm 1.43^{\mathrm{d}}$ & $0.70 \pm 0.002^{\mathrm{a}}$ \\
\hline G5 & $4.6 \pm 0.12^{a}$ & $2.61 \pm 0.06^{\mathrm{d}}$ & $1.76 \pm 0.012^{b}$ & $90.2 \pm 2.00^{b}$ & $0.67 \pm 0.002^{\mathrm{a}}$ \\
\hline G6 & $4.1 \pm 0.10^{b}$ & $3.59 \pm 0.07^{\mathrm{b}}$ & $1.14 \pm 0.010^{\mathrm{d}}$ & $58.21 \pm 1.21^{\mathrm{d}}$ & $0.72 \pm 0.002^{\mathrm{a}}$ \\
\hline G7 & $4.6 \pm 0.12^{a}$ & $2.71 \pm 0.06^{\mathrm{d}}$ & $1.69 \pm 0.013^{b c}$ & $86.6 \pm 2.00^{c}$ & $0.65 \pm 0.002^{\mathrm{a}}$ \\
\hline
\end{tabular}

G1: control Biscuits less color, G2: Biscuits turmeric powdered, G3: Biscuits contained cocoa powdered, G4: Biscuits contained tartrazine, G5: Biscuits contained chocolate brown powdered, G6: Biscuits contained mixture Turmeric / Tartrazine powdered, G7: Biscuits contained cocoa/ chocolate brown powdered. (a) Width of 5 biscuits in series, (b) Thickness of 5 biscuits in series, (c) Width/thickness and (d) spread ratio of Sample / spread ratio of control $\mathrm{x} 100$ Values are mean \pm SD of three replicates.

Table 7. Sensory evaluation of colored wheat flour biscuit made using different levels of turmeric and tartrazine powder

\begin{tabular}{ccccccc}
\hline Biscuit & Color (20) & Taste (20) & Oder (20) & Crust appearance (20) & Texture (20) & Overal Acceptability (100) \\
\hline Control & $18.1^{\mathrm{b}} \pm 1.2$ & $18.2^{\mathrm{b}} \pm 1.09$ & $19.0^{\mathrm{c}} \pm 1.0$ & $18.4^{\mathrm{cd}} \pm 0.97$ & $18.5^{\mathrm{bc}} \pm 0.1$ & $92.2^{\mathrm{b}} \pm 2.7$ \\
Tu & $18.4^{\mathrm{b}} \pm 1.2$ & $18.3^{\mathrm{b}} \pm 1.03$ & $19.3^{\mathrm{bc}} \pm 0.9$ & $18.6^{\mathrm{c}} \pm 1.01$ & $18.7^{\mathrm{bc}} \pm 0.9$ & $93.3^{\mathrm{ab}} \pm 3.0$ \\
Ta & $18.6^{\mathrm{a}} \pm 1.02$ & $18.7^{\mathrm{a}} \pm 0.98$ & $19.7^{\mathrm{a}} \pm 0.79$ & $18.9^{\mathrm{b}} \pm 0.10$ & $18.9^{\mathrm{b}} \pm 1.0$ & $94.8 \pm 3.0^{\mathrm{ab}}$ \\
MTT & $18.8^{\mathrm{a}} \pm 1.2$ & $19.3^{\mathrm{a}} \pm 1.10$ & $20.0^{\mathrm{a}} \pm 1.07$ & $19.4^{\mathrm{a}} \pm 1.0$ & $19.3^{\mathrm{a}} \pm 1.10$ & $96.8 \pm 3.1^{\mathrm{a}}$ \\
\hline
\end{tabular}

Values are mean \pm SD of three-replicate control: control less color biscuits, Tu: tumaric biscuits, Ta: tartrazine biscuits, MTT: mixture tartrazine and turmeric 
Table 8. Sensory evaluation of colored wheat flour biscuit made using different levels of cocoa and chocolate brown powder

\begin{tabular}{ccccccc}
\hline Biscuit & Color (20) & Taste (20) & Oder (20) & Crust Appearance (20) & Texture (20) & Overall Acceptability (100) \\
\hline Control & $18.1^{\mathrm{bc}} \pm 0.46$ & $18.3^{\mathrm{bc}} \pm 0.50$ & $18.6^{\mathrm{cd}} \pm 0.41$ & $18.5^{\mathrm{cd}} \pm 0.34$ & $18.2^{\mathrm{b}} \pm 0.29$ & $95.70^{\mathrm{a}} \pm 1.99$ \\
$\mathrm{CO}$ & $18.2^{\mathrm{bc}} \pm 0.51$ & $18.5^{\mathrm{ab}} \pm 0.37$ & $18.8^{\mathrm{c}} \pm 0.31$ & $18.7^{\mathrm{c}} \pm 0.42$ & $18.3^{\mathrm{b}} \pm 0.31$ & $96.5^{\mathrm{a}} \pm 2.01$ \\
$\mathrm{Cb}$ & $18.6^{\mathrm{b}} \pm 0.29$ & $18.9^{\mathrm{ab}} \pm 0.42$ & $19.2^{\mathrm{b}} \pm 0.50$ & $19.1^{\mathrm{ab}} \pm 0.50$ & $18.6^{\mathrm{a}} \pm 0.30$ & $97.4^{\mathrm{a}} \pm 2.87$ \\
$\mathrm{MCC}$ & $18.9^{\mathrm{a}} \pm 0.46$ & $19.3^{\mathrm{a}} \pm 0.36$ & $19.7^{\mathrm{a}} \pm 0.37$ & $19.6^{\mathrm{a}} \pm 0.48$ & $18.8^{\mathrm{a}} \pm 0.29$ \\
\hline Val & & $96.3^{\mathrm{a}} \pm 2.11$ & \\
\hline
\end{tabular}

Values are mean \pm SD of three-replicates, control: control less color biscuits, CO: cacao biscuits, Cb: chocolate brown biscuits, MCC: mixture cacao and chocolate brown biscuits.

The chemical composition of barley flour biscuit

Barley has not yet been used as the main ingredient in such common food commodities as bread and biscuit. Barley grain is an excellent source of both soluble and insoluble dietary fibers. Barley $\beta$-glucans are recognized to have important positive health impacts. Consequently, partial replacement of wheat with whole barley may result in development of acceptable and functional products.

The proximate chemical composition of biscuit samples prepared from different samples, synthetic color and natural color is given in Table 9. Results showed that the addition of barley in the color biscuit improved the protein, ash and crude fiber of biscuit samples. Consists of the normal characteristics of biscuits, their moisture content was generally below 5\%. The lower level of moisture is an important property of biscuits, which contributes to their keeping quality and crisp texture. Moisture content of biscuit samples in present study ranged from 2.32 to $4.32 \%$, due to protein and fiber contents of barley which give highwater absorption, moisture binding capacity as well as lubricity. These results are in agreement with those obtained by Mamat et al. (2010) who reported that the typical initial moisture content of biscuit dough ranges from $11-30 \%$, comprising both water added at the dough mixing stage and naturally occurring water in the ingredients. Thermal processing reduces the final moisture content to $1-5 \%$ in the final product.

It could be seen from the results that the protein, ash, fat and crude fiber contents were increased in obtaining functional biscuit samples by barley with different color. The fat content of biscuits was decreased by $2.5 \%$ and $2.3 \%$ as compared to control sample with tartrazine and mixture color.

The mean values for total dietary fiber content of biscuits are presented in Table 9. It was observed that control biscuits had $14.82 \%$ of total dietary fiber, on dry weight. Barley biscuits contained higher amount of total fiber as compared to wheat flour biscuits.

The dietary fiber constituents increased significantly $(\mathrm{p}$ $\leq 0.05$ ) in biscuits containing barley. In comparison to control samples significant increase of total dietary fiber content was achieved by addition of barley these results are in agreement with those obtained by fiber of biscuit samples. Consistent with the normal previous studies showed that significant increase of total dietary fiber content was achieved by addition of $30 \%$ barley meal (Vitali et al., 2007).

In Table 10 where it was observed that barley supplementation improves nutritional status of malnourished children. Desai et al. (2010) showed that iron
(189.3\%) and calcium (12.53\%) were found in barley flour biscuits when compared to control wheat flour biscuits. Results showed that minerals, especially calcium, phosphorus and iron in barley flour higher as compared to wheat flour biscuits as supported by previous studies (King et al., 2008).

Table 11 showed that physical properties of colored biscuits by barley flour observed. The low moisture content for barley flour is effect on the physical properties, width, thickness and spread ratio. This parameter is very important not only for flours shelf life, but also for the determining of solids content. For many tests, it is necessary to know dry weight for the material in order to determine the amount of substances it contains (Freund and Kim, 2006).

The diameter and thickness slightly decreased with barley flour with chocolate brown and tartrazine. The diameter and thickness slightly decreased compared with the control. While density at all the biscuit colorant powder had the same values compared with the control. This is possibly due to the addition the barley improvement physical properties of colored biscuits.

\section{Sensory evaluation of functional barley biscuits}

The influence of barley flour in biscuit formula on the sensory attributes of the prepared color biscuits was studied. Results of sensory evaluation in terms of appearance of crust, texture, color, odor, taste, and overall acceptability of biscuits samples supplemented with different levels of color are presented in Table 12. It was observed that significant differences were found between biscuits samples supplemented with color by barley and the control sample. Biscuits containing of turmeric with barley flour showed mean maximum overall acceptability $90.2 \%$ compared to control barley biscuit sample 77.6\%. In general, fortification of biscuits with barley flour by color significantly improved color, crust, texture than control sample.

In Table 13 biscuits were standardized by barley flour at different levels of synthetic and natural colors with different taste, color with cocoa powder, chocolate brown and mixture color, biscuits having chocolate brown and mixing color were found to be most acceptable in appearance, color, texture and overall acceptability $95.9 \%$ and $94.9 \%$ respectively. Whereas biscuit color by cocoa powder were found to be most acceptable in taste $19.4 \%$ and $19.7 \%$ for different levels. The numbers of panel with highly significant compared to control with cocoa powder. The obtained results are in good agreement with those reported by Sharma and Chopra (2015) who reported that that biscuits supplemented with a higher level of fiber from sources of barley are more acceptable than lower levels. 
36

Table 9. Chemical composition (\%) of colored barley flour biscuit contained different levels of natural and synthetic color

\begin{tabular}{cccccccc}
\hline Biscuit & Moisture & Ash & Protein & Crude fiber & Fat & Carbohydrate & Dietary fiber \\
\hline G1 & $4.23 \pm 0.10^{\mathrm{a}}$ & $1.49 \pm 0.02^{\mathrm{b}}$ & $9.30 \pm 0.21^{\mathrm{c}}$ & $0.43 \pm 0.01^{\mathrm{c}}$ & $14.0 \pm 0.22^{\mathrm{b}}$ & $74.15 \pm 2.00^{\mathrm{a}}$ & $14.82 \pm 0.29^{\mathrm{a}}$ \\
G2 & $3.90 \pm 0.08^{\mathrm{b}}$ & $1.61 \pm 0.03^{\mathrm{a}}$ & $11.44 \pm 0.24^{\mathrm{a}}$ & $0.83 \pm 0.02^{\mathrm{a}}$ & $14.9 \pm 0.39^{\mathrm{a}}$ & $72.15 \pm 1.97^{\mathrm{ab}}$ & $14.97 \pm 0.21^{\mathrm{a}}$ \\
G3 & $3.91 \pm 0.05^{\mathrm{b}}$ & $1.48 \pm 0.01^{\mathrm{b}}$ & $11.40 \pm 0.18^{\mathrm{a}}$ & $0.66 \pm 0.01^{\mathrm{b}}$ & $14.9 \pm 0.44^{\mathrm{a}}$ & $74.11 \pm 1.98^{\mathrm{a}}$ & $14.22 \pm 0.17^{\mathrm{c}}$ \\
G4 & $2.56 \pm 0.06^{\mathrm{c}}$ & $1.48 \pm 0.02^{\mathrm{b}}$ & $10.01 \pm 0.20^{\mathrm{b}}$ & $0.66 \pm 0.02^{\mathrm{b}}$ & $14.4 \pm 0.22^{\mathrm{ab}}$ & $73.23 \pm 2.01^{\mathrm{a}}$ & $14.59 \pm 0.18^{\mathrm{b}}$ \\
G5 & $4.11 \pm 0.08^{\mathrm{a}}$ & $1.40 \pm 0.02^{\mathrm{c}}$ & $9.30 \pm 0.20^{\mathrm{c}}$ & $0.65 \pm 0.01^{\mathrm{b}}$ & $9.2 \pm 0.23^{\mathrm{d}}$ & $72.40 \pm 2.06^{\mathrm{bb}}$ & $14.30 \pm 0.11^{\mathrm{c}}$ \\
G6 & $2.50 \pm 0.06^{\mathrm{c}}$ & $1.39 \pm 0.01^{\mathrm{c}}$ & $10.01 \pm 0.19^{\mathrm{b}}$ & $0.45 \pm 0.01^{\mathrm{c}}$ & $10.1 \pm 0.32^{\mathrm{c}}$ & $73.41 \pm 1.89^{\mathrm{a}}$ & $14.12 \pm 0.35^{\mathrm{cd}}$ \\
G7 & $2.32 \pm 0.05^{\mathrm{c}}$ & $1.41 \pm 0.02^{\mathrm{c}}$ & $10.00 \pm 0.17^{\mathrm{b}}$ & $0.43 \pm 0.01^{\mathrm{c}}$ & $13.9 \pm 0.40^{\mathrm{b}}$ & $72.44 \pm 1.74^{\mathrm{bb}}$ & $14.10 \pm 0.34^{\text {cd }}$ \\
\hline
\end{tabular}

G1: control Biscuits less color, G2: Biscuits turmeric powdered, G3: Biscuits contained cocoa powdered, G4: Biscuits contained tartrazine, G5: Biscuits contained chocolate brown powdered, G6: Biscuits contained mixture Turmeric / Tartrazine powdered, G7: Biscuits contained cocoa/ chocolate brown powdered.

Values are mean \pm SD of three-replicates (triplicates).

Table 10. Element contents of the colored barley flour biscuit made using the natural color and synthetic color ( $\mathrm{mg} / 100 \mathrm{~g}$ dry weight)

\begin{tabular}{ccccccccc}
\hline Biscuit & $\mathrm{Na}$ & $\mathrm{K}$ & $\mathrm{Mg}$ & $\mathrm{Fe}$ & $\mathrm{Zn}$ & $\mathrm{Ca}$ & $\mathrm{P}$ & $\mathrm{Cr}$ \\
\hline G1 & $0.31 \pm 0.002^{\mathrm{f}}$ & $0.85 \pm 0.01^{\mathrm{g}}$ & $0.29 \pm 0.001^{\mathrm{e}}$ & $1.07 \pm 0.01^{\mathrm{a}}$ & $0.01 \pm 0.001^{\mathrm{c}}$ & $40.2 \pm 0.30^{\mathrm{d}}$ & $0.98 \pm 0.004^{\mathrm{d}}$ & $\cdots$ \\
G2 & $1.22 \pm 0.006^{\mathrm{d}}$ & $74.37 \pm 0.41^{\mathrm{a}}$ & $5.41 \pm 0.03^{\mathrm{d}}$ & $1.07 \pm 0.01^{\mathrm{a}}$ & $0.19 \pm 0.002^{\mathrm{a}}$ & $41.5 \pm 0.29^{\mathrm{c}}$ & $9.54 \pm 0.051^{\mathrm{c}}$ & $20.4 \pm 0.09^{\mathrm{a}}$ \\
G3 & $2.91 \pm 0.011^{\mathrm{b}}$ & $64.21 \pm 0.44^{\mathrm{c}}$ & $12.35 \pm 0.11^{\mathrm{b}}$ & $1.04 \pm 0.01^{\mathrm{a}}$ & $0.09 \pm 0.001^{\mathrm{b}}$ & $42.7 \pm 0.27^{\mathrm{b}}$ & $17.50 \pm 0.21^{\mathrm{a}}$ & $\cdots$ \\
G4 & $1.34 \pm 0.0 \mathrm{f}^{\mathrm{d}}$ & $20.15 \pm 0.11^{\mathrm{e}}$ & $5.51 \pm 0.32^{\mathrm{d}}$ & $1.03 \pm 0.008^{\mathrm{a}}$ & $0.20 \pm 0.001^{\mathrm{a}}$ & $40.2 \pm 0.22^{\mathrm{d}}$ & $0.61 \pm 0.003^{\mathrm{e}}$ & $\cdots$ \\
G5 & $0.40 \pm 0.002^{\mathrm{c}}$ & $0.96 \pm 0.005^{\mathrm{f}}$ & $0.32 \pm 0.002^{\mathrm{e}}$ & $1.03 \pm 0.007^{\mathrm{a}}$ & $0.02 \pm 0.001^{\mathrm{c}}$ & $40.1 \pm 0.29^{\mathrm{d}}$ & $0.89 \pm 0.005^{\mathrm{de}}$ & $\cdots$ \\
G6 & $3.60 \pm 0.012^{\mathrm{a}}$ & $71.33 \pm 0.46^{\mathrm{b}}$ & $6.96 \pm 0.002^{\mathrm{c}}$ & $1.03 \pm 0.009^{\mathrm{a}}$ & $0.02 \pm 0.001^{\mathrm{c}}$ & $42.5 \pm 0.28^{\mathrm{b}}$ & $0.60 \pm 0.003^{\mathrm{e}}$ & $20.0 \pm 0.11^{\mathrm{b}}$ \\
G7 & $2.61 \pm 0.013^{\mathrm{c}}$ & $60.21 \pm 0.42^{\mathrm{d}}$ & $13.35 \pm 0.10^{\mathrm{a}}$ & $1.03 \pm 0.008^{\mathrm{a}}$ & $0.02 \pm 0.001^{\mathrm{c}}$ & $43.1 \pm 0.29^{\mathrm{a}}$ & $16.50 \pm 0.02^{\mathrm{b}}$ & $\cdots$ \\
\hline
\end{tabular}

G1: control Biscuits less color, G2: Biscuits turmeric powdered, G3: Biscuits contained cocoa powdered, G4: Biscuits contained tartrazine, G5: Biscuits contained chocolate brown powdered, G6: Biscuits contained mixture Turmeric / Tartrazine powdered, G7: Biscuits contained cocoa/ chocolate brown powdered.

Values are mean $\pm S D$ of three replicates

Table 11. Physical properties of colored barley flour biscuit made using the natural color and synthetic color (mg / $100 \mathrm{~g}$ dry weight)

\begin{tabular}{|c|c|c|c|c|c|}
\hline Biscuit & Widith $^{\mathrm{s}}(\mathrm{cm})$ & Thickness $^{\mathrm{b}}(\mathrm{cm})$ & Spread ratio $^{c}$ & Spread factor $^{\mathrm{d}}$ & Density $\mathrm{g} / \mathrm{cm}^{3}$ \\
\hline G1 & $4.6 \pm 0.14^{a}$ & $2.35 \pm 0.08^{\mathrm{c}}$ & $1.95 \pm 0.05^{a}$ & $100 \pm 3.32^{\mathrm{a}}$ & $0.64 \pm 0.01^{b}$ \\
\hline G2 & $4.1 \pm 0.13^{b}$ & $2.60 \pm 0.08^{d}$ & $1.57 \pm 0.06^{c}$ & $92.01 \pm 4.00^{\mathrm{b}}$ & $0.67 \pm 0.02^{b}$ \\
\hline G3 & $4.2 \pm 0.12^{b}$ & $3.81 \pm 0.11^{\mathrm{a}}$ & $1.10 \pm 0.03^{\mathrm{d}}$ & $61.03 \pm 2.14^{\mathrm{d}}$ & $0.70 \pm 0.03^{\mathrm{a}}$ \\
\hline G4 & $4.6 \pm 0.12^{\mathrm{a}}$ & $3.00 \pm 0.08^{c}$ & $1.53 \pm 0.02^{\mathrm{c}}$ & $102 \pm 3.41^{\mathrm{a}}$ & $0.64 \pm 0.02^{\mathrm{b}}$ \\
\hline G5 & $4.6 \pm 0.13^{\mathrm{a}}$ & $2.61 \pm 0.07^{\mathrm{d}}$ & $1.76 \pm 0.03^{\mathrm{b}}$ & $90.2 \pm 3.62^{b}$ & $0.67 \pm 0.02^{b}$ \\
\hline G6 & $4.1 \pm 0.12^{b}$ & $3.59 \pm 0.10^{b}$ & $1.14 \pm 0.02^{\mathrm{d}}$ & $58.21 \pm 2.01^{d}$ & $0.72 \pm 0.03^{\mathrm{a}}$ \\
\hline G7 & $4.6 \pm 0.12^{\mathrm{a}}$ & $2.71 \pm 0.07^{\mathrm{d}}$ & $1.69 \pm 0.02^{b}$ & $86.6 \pm 3.17^{c}$ & $0.65 \pm 0.02^{\mathrm{b}}$ \\
\hline
\end{tabular}

G1: control Biscuits less color, G2: Biscuits turmeric powdered, G3: Biscuits contained cocoa powdered, G4: Biscuits contained tartrazine, G5: Biscuits contained chocolate brown powdered, G6: Biscuits contained mixture Turmeric / Tartrazine powdered, G7: Biscuits contained cocoa/ chocolate brown powdered. (a) Width of 5 biscuits in series, (b) Thickness of 5 biscuits in series, (c) Width/thickness, (d) spread ratio of Sample / spread ratio of control x 100. Values are mean \pm SD of three replicates.

Table 12. Sensory evaluation of colored barley flour biscuits using different levels of turmeric and tartrazine powder

\begin{tabular}{ccccccc}
\hline Biscuit & Color $(20)$ & Taste (20) & Oder (20) & Crust appearance (20) & Texture (20) & Overall Acceptability (100) \\
\hline Control & $16.93 \pm 0.40^{\mathrm{c}}$ & $16.07 \pm 0.53^{\mathrm{g}}$ & $16.00 \pm 0.39^{\mathrm{c}}$ & $17.07 \pm 0.40^{\mathrm{c}}$ & $16.47 \pm 0.16^{\mathrm{d}}$ & $77.60 \pm 2.31^{\mathrm{c}}$ \\
Tul & $18.53 \pm 0.29^{\mathrm{b}}$ & $17.73 \pm 0.27^{\mathrm{b}}$ & $17.67^{\mathrm{d}} \pm 0.37$ & $18.40 \pm 0.11^{\mathrm{b}}$ & $16.73 \pm 0.22^{\mathrm{c}}$ & $90.20 \pm 1.72^{\mathrm{a}}$ \\
Tal & $18.86 \pm 0.26^{\mathrm{a}}$ & $18.20 \pm 0.23^{\mathrm{a}}$ & $17.87^{\mathrm{d}} \pm 0.38$ & $18.80 \pm 0.34^{\mathrm{a}}$ & $17.20 \pm 0.33^{\mathrm{b}}$ & $88.27 \pm 1.86^{\mathrm{b}}$ \\
MTT1 & $18.80 \pm 0.33^{\mathrm{a}}$ & $18.53 \pm 0.3^{\mathrm{a}}$ & $18.13^{\mathrm{c}} \pm 0.32$ & $18.93 \pm 0.23^{\mathrm{a}}$ & $18.07 \pm 0.41^{\mathrm{a}}$ & $87.40 \pm 1.99^{\mathrm{b}}$ \\
\hline
\end{tabular}

Values are mean \pm SD of three-replicate control:control less color biscuits, Tu: tumaric biscuits, Ta: tartrazine biscuits, MTT: mixture tartrazine and turmeric

Table 13. Sensory evaluation of colored barley flour biscuit made using different levels of cocoa and chocolate brown powder

\begin{tabular}{ccccccc}
\hline Biscuit & Color (20) & Taste (20) & Oder (20) & Crust Appearance (20) & Texture (20) & Overall Acceptability (100) \\
\hline Control & $18.0 \pm 0.17^{\mathrm{b}}$ & $18.3 \pm 0.17^{\mathrm{c}}$ & $18.0 \pm 0.18^{\mathrm{c}}$ & $18.5 \pm 0.19^{\mathrm{c}}$ & $19.2 \pm 0.21^{\mathrm{a}}$ & $92.00 \pm 0.41^{\mathrm{c}}$ \\
$\mathrm{CO}$ & $18.2 \pm 0.28^{\mathrm{b}}$ & $19.4 \pm 0.28^{\mathrm{a}}$ & $19.2 \pm 0.20^{\mathrm{a}}$ & $19.7 \pm 0.20^{\mathrm{a}}$ & $18.9 \pm 0.27^{\mathrm{a}}$ & $95.4 \pm 0.32^{\mathrm{a}}$ \\
$\mathrm{Cb}$ & $18.7 \pm 0.17^{\mathrm{a}}$ & $18.8 \pm 0.23^{\mathrm{b}}$ & $18.2 \pm 0.10^{\mathrm{c}}$ & $19.1 \pm 0.32^{\mathrm{b}}$ & $19.1 \pm 0.24^{\mathrm{a}}$ & $93.9 \pm 0.49^{\mathrm{b}}$ \\
$\mathrm{MC} 1$ & $18.9 \pm 0.18^{\mathrm{a}}$ & $18.3 \pm 0.09^{\mathrm{c}}$ & $18.7 \pm 0.29^{\mathrm{b}}$ & $19.6 \pm 0.37^{\mathrm{a}}$ & $19.4 \pm 0.23^{\mathrm{a}}$ & $94.9 \pm 0.41^{\mathrm{ab}}$ \\
\hline
\end{tabular}

Values are mean \pm SD of three-replicates, control: control less color biscuits, CO: cacao biscuits, Cb: chocolate brown biscuits, MCC: mixture cacao and chocolate brown biscuits. 


\section{Conclusions}

Finally, the results of the sensory evaluation to biscuit showed that biscuits with synthetic color were most acceptable having highest overall acceptability in color, crust and texture scores than natural color. Chemical analysis of barley biscuit flour revealed that all the biscuits having significantly higher amount of protein, dietary fiber, ash and elements content than the biscuits prepared from wheat flour also a non-significant difference was found in fat content of all the biscuits. Composite flour biscuits contained significantly high amount of total dietary fiber in barley biscuits compared to wheat flour biscuits.

\section{References}

Abdel-Rahim EA, Ahmed EA, El-Desoky GE, Ramadan ME (1987). Biochemical role of some natural and synthetic colorants on liver function of rats. Minia Journal of Agriculture Research and Development 9:11-17.

Ajibola CF, Oyerinde VO, Adeniyan OS (2015). Physicochemical and antioxidant properties of whole-wheat biscuits incorporated with Moringa oleifera leaves and cocoa powder. Journal of Scientific Research and Reports 7(3):195-206.

Ammon H, Wahl MA (1991). Biological activities of turmeric (Curcuma longa). Planta Medica 57:1-7.

AOAC (2000). Official methods of analysis of the association of official analytical chemists 17Ed, Washington, D.C., USA.

Barrett A, Cooper A, Crumpler D, Dalen L, Grimshaw K, ... Stevenson J (2007). Food additives and hyperactive behaviour in 3-year old and 8/9year-old children in the community: a randomised, double-blinded, placebo controlled trial. Lancet 370(9598):1560-1567.

Boskou D, Dusemund B, Gott D (2010). Panel on food additives and nutrient sources added to food (ANS), scientific opinion on the reevaluation of curcumin (E 100) as a food additive. European Food Safety Authority Journal 8(9):1943-1983.

Brennan CS, Cleary LJ (2005). The potential use of cereal (1-3), (1-4)-( $\beta$-dglucans as functional food ingredients. Journal of Cereal Science $42(1): 1$ 13.

Dahab DB (2006). Utilization of different cereal flour mixes in the preparation of some Bakery products. M.Sc Thesis, Food Sci. and Technol.Dept, Fac. Agric, Cairo Univ, Egypt.

Desai AD, Kulkarni SS, Sahoo AK, Ranveer RC, Dandge PB (2010). Effect of supplementation of malted ragi flour on the nutritional and sensorial quality characteristics of cake. Advance Journal of Food Science and Technology 2(1):67-71.

Drisya CR, Swetha BG, Velu V, Indrani D, Singh RP (2015). Effect of dried Murraya koenigiileaves on nutritional, textural and organoleptic characteristics of cookies. Journal of Food Science and Technology 52(1):500-506.

El-Beltagi HS, Abdel-Rahim EA (2017). Biochemical changes in fatty acids, hydrocarbons and sterols as well as total lipids of albino rats ingested some synthetic colourants and flavourants as food additives. Notulae Scientia Biologicae 9(1):40-47.
FAO/WHO (1985). Food Additives Data System, Food and Agriculture Organization of the United Nations, Rome, 30/Rev.1.

Farhath K, Sudaeshanakrishna, KR, Semwal AD, Vishwanathan KR, Khanum F (2001). Proximate composition and mineral contents of spices. Indian Journal of Nutrition and Dietetics 38:93-97.

Feng J, Cerniglia CE, Chen H (2012). Toxicological significance of azo dye metabolism by human intestinal microbiota. Frontiers in Bioscience Journal $4(4): 568-586$.

Freund F, Kim MY (2006). Future of flour: A compendium of flour improvement. In: Popper L, Schäfer W, Freund W (Eds.), Clenze, Germany,pp 101-116.

Gyedu-Akoto E, Laryea D (2013). Evaluation of cassava flour in the production of cocoa powder-based biscuits. Nutrition and Food Science 43(1):55-59.

Hassan A, Nagwa M, Mervat I, Wafaa K (2012). Production of functional biscuits for lowering blood lipids. World Journal of Dairy and Food Sciences 7(1):1-20.

Jackson FJ, Read JI, Lucas BE (1980). Determination of total chromium, cobalt and silver in food stuffs by flame atomic absorption spectrophotometry. Analyst 105(1249):359-370.

Karl JP, Saltzman E (2012). The role of whole grains in body weight regulation. Advances in Nutrition 3(5):697-707.

King RA, Noakes M, Bird AR, Morell MK, Topping DL (2008). An extruded breakfast cereal made from a high amylose barley cultivar has a low glycemic index and lower plasma insulin response than one made from astandard barley.Journal ofCereal Science 48(2):526-530.

Lee KW, Kim YJ, Lee HJ, Lee CY (2003). Cocoa has more phenolic phytochemicals and a higher antioxidant capacity than teas and red wine. Journal of Agricultural and Food Chemistry 51(25):7292-7295.

Mamat H,Abu Hardan MO, Hill SE (2010). Physicochemical properties of commerc al semi-sweet biscuit. Food Chemistry 121:1029-1038.

Manohar RS, Rao PH (1997). Effect of mixing period and additives on the rheological characteristics of dough and quality of biscuits. Journal of Cereal Science 25(2):197-206.

MacGregor AW, Fincher GB (1993). Carbohydrates of the barley grain. In: Barley: Chemistry and Technology (eds. W. MacGregor, R. S. Bhatty). AACC,St. Paul,USA, pp 73-130.

Mckeown NM, Jacques PF, Seal CJ, de Vries J, Jonnalagadda SS, ... Marquart LF (2013). Whole grains and health: from theory to practice: highlights of the grains for health foundation's whole grains summit 2012. Journal of Nutrition 143(5):744S-758S.

McWatters KH (1978). Cookie baking properties of defatted peanut, soybean and field pea flours. Cereal Chemistry 55:853-863.

Monagas M, Khan N, Andres-Lacueva C, Casas R, Urpi'-Sarda M, ... Estruc R (2009). Effect of cocoa powder on the modulation of inflammatory biomarkers in patients at high risk of cardiovascular disease. American Journal of Clinical Nutrition 90(5):11441150.

Prosky L, Furda I, Devries JW, Schweizer TF, HardLand BF (1984). Determination of total dietary fiber in foods, food products, and total diets, inter laboratory study. Journal of the Association of Official Analytical Chemists 67:10441052.

Sharma S, Chopra R (2015). Nutritional, sensory and textural analysis of biscuits supplemented with malted barley (Hordeum vulgare). International Journal of Food and Nutritional Sciences 4:97-101. 
38

Sharma P, Velu V, Indrani, D, Singh R (2013). Effect of dried Guduchi (Tinospora cordifolia) leaf powder on rheological, organoleptic and nutritional characteristics of cookies. Food Research International 50(2):704709.

Stahl L, Miller KB, Apgar J, Sweigart DS, Stuart DA, ... Hurst WJ (2009). Preservation of cocoa antioxidant activity, total polyphenols, flavan-3-ols, and procyanidin content in foods prepared with cocoa powder. Journal ofFood Science 74(6):456-461.

Sudha ML, Vetrimani R, Leelavathi K (2007). Influence of fiber from different cereals on the rheological characteristics of wheat flour dough and on biscuit quality. Food Chemistry 100(4):1365-1370.
Vitali D, Dragojević IV, Šebečić B, Vujić L (2007). Impact of modifying teabiscuit composition on phytate levels and iron content and availability. Food Chemistry 102(1):82-89.

Wade P (1988). Biscuits, cookies and crackers. Vol. 1. Recipe of biscuit used during investigation. Applied Science Pulishers LTD, London, UK, pp 102-114.

WaltonK, Walker R, Van De Sandt JJ, Castell JV, Knapp AA, ... Schilter B (1999). The application of in vitro data in the derivation of the acceptable daily intake of food additives. Food and Chemical Toxicology 37(12):1175-1197. 